Biological Conservation

February 2017, Volume 206, Pages 258-262

http://dx.doi.org/10.1016/i.biocon.2016.11.036

http://archimer.ifremer.fr/doc/00361/47215/

(C) 2016 Elsevier Ltd. All rights reserved.

\title{
Biodiversity offsetting: Clearing up misunderstandings between conservation and economics to take further action
}

\author{
Vaissière Anne-Charlotte ${ }^{1,{ }^{*}}$, Levrel Harold ${ }^{2}$, Scemama Pierre ${ }^{3}$
}

1 UMR 5474 LAMETA CNRS, Université de Montpellier, Faculté d'économie, Avenue Raymond Dugrand, F-34960 Montpellier, France

2 UMR 8568 CIRED, AgroParisTech, Campus du Jardin Tropical, 45 bis, avenue de la Belle Gabrielle, F-94736 Nogent-sur-Marne, France

${ }^{3}$ IFREMER, UMR 6308 AMURE, Rue Dumont d'Urville, F-29280 Plouzané, France

* Corresponding author : Anne-Charlotte Vaissière, email address : anne.charlotte.vaissiere@gmail.com

\begin{abstract}
:
Biodiversity offsetting (BO) is increasingly adopted as a conservation tool by many countries while it has received several critics among which its possible links to several forms of Nature economicization. We believe that some of these concerns rest on misunderstandings generated by the difficulty to interpret economic principles from ecological viewpoints and the lack of a common language between conservationists and economists. Because this issue is vivid and the concepts not yet stabilized, key aspects of the potential advances and limits of $\mathrm{BO}$ to conservation practice must be clarified. This short communication (1) addresses the links between the BO concept and the central sustainability principle and (2) clarifies key assumptions regarding three potential Nature economicization roles recurrently attributed to $\mathrm{BO}$. We show that the $\mathrm{BO}$ principle reflects a move from welfare equivalency mostly inherited from mainstream economic approach based on weak sustainability criteria toward an ecological economic approach based on strong sustainability criteria and the quest for ecological equivalence. However, the way the countries implement BO influences the possibility to reach strong sustainability. Although we show that BO could be linked to a certain acceptance of "commodification", we suggest that BO can neither be considered as a "marketization" and nor generally as a "privatization" of Nature. We therefore argue that these conceptual misunderstandings should not hamper conservation objectives and that $\mathrm{BO}$ must be framed within interdisciplinary approaches combining ecology, economy and socio-political aspects. We conclude that conservation science has a major role to play in defining the boundaries of $\mathrm{BO}$.
\end{abstract}




\section{Highlights}

- Biodiversity offsetting is often criticized because of a use of "economics" logics. But the biodiversity offsetting principle is rather linked to strong sustainability. We clarified the possible commodification, marketization and privatization of Nature. Beyond theoretical blocks, biodiversity offsetting implementation must be improved. Biological conservation must help defining the boundaries of biodiversity offsetting.

Keywords: Biodiversity offsetting, Sustainability, Commodification, Marketization, Privatization, Ecological restoration 


\section{1- Introduction}

Biodiversity offsetting (BO) has received a surge of interest these last years by the academic, political and civil society spheres (Calvet et al., 2015). The principle of this public policy tool is to reach a no net loss (NNL) goal of biodiversity through the compensation of residual impacts of development projects on biodiversity by ecological restoration measures implemented offsite (i.e. out of the impacted site). In most of the countries where such a policy exists (45 countries already actively use BO, see Madsen et al. (2011) for a review), developers must follow a mitigation hierarchy including steps to first avoid, then reduce and, as a last resort, offset significant residual impacts on protected biodiversity. For us, and for many researchers and international organizations, "biodiversity offsetting" addresses endangered species but also various protected habitats and ecosystems such as wetlands.

In a recent special issue published in Biological Conservation, $\mathrm{BO}$ are said to represent both "the dream and the nightmare of conservation" (Devictor, 2015 p.484). Indeed, on the one hand, BO can be considered in line with a main goal of biological conservation, as a promising tool to stop the erosion of biodiversity. On the other hand, however, some people find a structural incompatibility of BO with conservation since it starts with destruction. This new tool is thus regularly denounced as a way to facilitate development projects and as creating tensions and competition with existing conservation tools (Gordon et al., 2015; Ives and Bekessy, 2015; Walker et al., 2009). Beyond its very principle, a poor implementation of BO - caused by negligence or weak knowledge and practices - was showed to jeopardize its ability to get closer to the NNL goal (Mack and Micacchion, 2006; Matthews and Endress, 2008; Quigley and Harper, 2006). Overall, the current implementation of BO is not uniform worldwide and the very notion is not stabilized, including at the research level. It would be premature to pretend having a univocal opinion on this very active topic.

Many researchers in biological conservation and other disciplines are still working on the way to improve the knowledge and ecological performance of $\mathrm{BO}$ measures but also on the related socio-economic and organizational aspects. Although highlighting the limits of BO implementation is necessary, we believe that some of the most common critics of $\mathrm{BO}$ are not appropriate and might lead to interfere with the scientific discussions regarding the pros and cons of this policy tool with respect to biodiversity conservation objectives. Whether they focus on the very principle of BO or on the organizational and institutional innovations dedicated to it, we have noticed that such critics are often linked to a common concern regarding the use of "economic" logics or tools in the realm of nature conservation. Besides, Calvet et al. (2015) described an increasing use of the economic rhetoric within the BO context, although this rhetoric does not seem so new at the wider scale of public policies and other initiatives for nature conservation (Levrel and Missemer, 2016). In particular, BO has been tied to several keywords including commodification, substitution, sustainability, equivalence, privatization and marketization of Nature hence generating vivid debates. Rather than ending up as deadlocks, we argue that these discussions should lead to improve - rather than mask - the current frequently unsatisfying implementation of BO.

In this short communication, we highlight two central misunderstandings regarding economic concepts linked to the notion of BO (note that many others could be considered, e.g. Aubertin et al., 2016). We believe they are mainly caused by the difficulty to interpret economic principles from ecological viewpoints and vice e versa.

We thus propose to clarify two of the most controversial issues in order to go beyond a theoretical block and highlight the possible advances or limits for nature conservation. The first is the strong/weak sustainability principle in which the concept of BO is anchored (section 2). The second deals with the supposedly link between BO and commodification, marketization and privatization of Nature (section 3). We will not fully address these two points but we propose some clarifying definitions along with illustrative examples and references. We finally conclude on the practical implications of these discussions for biodiversity conservation and advocate for a more interdisciplinary approach of BO in which conservation must help to set the boundaries of BO.

\section{2 - Is biodiversity offsetting aligned with the weak or strong sustainability principle from an economic point of view?}

Among most regular critics of BO the potential connection between this tool and neoliberal economics is often stated (e.g. Apostolopoulou and Adams, 2015; Feydel and Bonneuil 2015; Ives and Bekessy, 2015; Robertson, 
2004; Spash, 2015). To understand what is at stake, however, it is necessary to emphasize the plurality of economic schools and their major assumptions related to the central idea of "sustainability". The concept of sustainability does not have a unique and shared definition among disciplines and has different meanings depending on the context (Brown et al., 1987). The most popular definition of sustainability is associated with the concept of "development" (e.g., see the largely cited and used IUCN (1990) definition of "sustainable development"). In this case, the basic idea of sustainability is to consider numerous types of relations between humans and the environment. In the case of BO, sustainability has a more specific meaning and reflects the ways to manage the impacts of humans on Nature. From an economic perspective, sustainability can range from "weak" to "strong". A weak sustainability corresponds to a situation where biodiversity can be replaced by nonnatural elements considered to be equivalent. In contrast, assuming a strong sustainability prevents from genuine substitution of biodiversity by non-natural components. In other words, if the goal of BO is to reach the NNL of biodiversity, this tool will represent an interesting conceptual shift from usual weak sustainability to stronger a one.

More precisely, weak and strong sustainability are derived from the compensation principle, initially based on the theory of social utilitarism within the perspective of welfare economics. Within the context of projects having impacts on biodiversity, this approach considers that human populations derive a utility from Nature. Thus, a destruction of some natural components (considered as belonging to a "natural capital") is acceptable only if it is at least counterbalanced by the economic growth (considered as an increase of "physical capital"). This famous Kaldor-Hicks compensation criterion (Hicks, 1939; Kaldor, 1939) requires calculating how much benefits a project provides for a human population and how much costs this project generates for another human population. If the benefits are higher than the costs, part of the benefit to the first human population will be devoted to compensate for the losses of the second human population. Such an ideal project will create a net positive impact for the whole human population. Note that regarding biodiversity the underlying assumption is that biodiversity is substitutable with physical capital once it creates economic wealth, and that it is possible to compensate the damages suffered by people who have been injured by these impacts. This first type of compensation, that can be named "monetary compensation" of economic and well-being losses, was the most common form of compensation used during the two last centuries (Fressoz, 2013). Indeed, this approach of the compensation principle only focuses on injuries to people. This is the reason why this criterion is considered to adopt a weak sustainability principle that underestimates the need for conserving biodiversity and dismisses the singularities of natural capital (Pearce and Atkinson, 1993; Ekins, 2003).

During the 70s, however, the concept of "biodiversity offsetting" appeared both in Europe and the US (Hough and Robertson, 2009; Levrel et al., 2015). The tenants of ecological economics advocated for a paradigm shift in considering that biodiversity must be compensated for itself. This economic school of thought, considered as "heterodox economics" compared to "mainstream" or "orthodox economics", has built most of its theoretical framework around the concept of strong sustainability (Costanza et al., 1991). Strong sustainability is based on the idea that the different forms of capital are complementary but not substitutable. It means that it is important to maintain a certain level of natural capital even when its decrease could generate gains of well-being. In noneconomic terms, this implies that it is no longer acceptable to substitute natural capital by manufactured capital and/or to compensate the injured people with money. From this angle, biodiversity offsets can be considered as a specific type of compensation that falls within a strong sustainability principle. In practice what a "certain level of natural capital" means must be carefully considered. In particular, the authorized level and conditions of substitutability, the decision rules to establish "ecological equivalence" or the difficulty to align the spatial and temporal dynamics of impacted and restored biodiversity represent major challenges.

Therefore, switching progressively from weak to strong sustainability as allowed by BO seems to represent a positive contribution to conservation at least as a setting of a more virtuous agenda. Table 1 shows several possible levels of equivalence and associated types of sustainability from an economic point of view within the context of BO. Levels 2 to 4 are different levels of strong sustainability with a decreasing interchangeability of natural capital leading to an increasing level of strong sustainability. While the level 4 seems to be the most appropriate to reach a NNL of biodiversity, most of the countries with a BO policy still have practices corresponding to levels 2 and 3. Level 4 actually splits up in several sub levels linked to a gradient of practices with regard to the ecological equivalence aim. For instance, biodiversity offsets have been originally - and this is still the case in many countries - sized on a "surface" basis. In other words, the destruction of one hectare is for instance simply replaced by an amount of hectares sometimes with ratios to take into account the uncertainty of ecological restoration (this approach can be equated to a low criteria as it simplifies biodiversity to a surface). 
The most advanced BO policies, like those ongoing in the US, have rather adopted a more functional approach in accounting for the conservation status of the impacted and restored areas. The latter approach is thus adopting high criteria but the real baseline of these ecosystems is still rarely taken into account when sizing the BO (Maron et al., 2015). For instance, if the restored area was anyway in a dynamic of natural regeneration, its gains would be necessarily overestimated and hence, some authorized losses never offset. This gradient can be completed by the inclusion of more specific definitions of what is considered to stand for interchangeable species and habitat. For instance, some BO policies may authorize to offset a wetland by another wetland elsewhere (quite low criteria) while others, as in the US, would only allow to offset a certain type of wetland in a sub-basin by the same type of wetland in the same sub-basin (high criteria). While the realism of level 5 (absolutely no loss of biodiversity is admitted) is open to question, one could consider that it is the only desirable solution to really stop biodiversity erosion. This level may however be difficult to accept because substitution helps society to be flexible in its uses of Nature and to cope with population increase or fight against poverty. In these countries, this type of argument is also used as a way to keep the level of requirements for the offsetting policy low (Quétier et al., 2014).

Table 1: Different levels of sustainability (fourth column) implied by different types of ecological equivalencies for substituting impact losses with offset gains (first column).

\begin{tabular}{|c|c|c|c|c|}
\hline & Equivalency level & Description & Example & Level of sustainability \\
\hline 0 & $\begin{array}{l}\text { Net loss of } \\
\text { biodiversity and } \\
\text { utility }\end{array}$ & $\begin{array}{l}\text { Natural capital is destroyed } \\
\text { without } \\
\text { offsetting/compensation }\end{array}$ & $\begin{array}{l}\text { Destruction of seagrass } \\
\text { by fishing gears }\end{array}$ & Not sustainable \\
\hline 1 & No net loss of utility & $\begin{array}{l}\text { Natural capital is replaced } \\
\text { by manufactured capital or } \\
\text { money with maintenance of } \\
\text { utility }\end{array}$ & $\begin{array}{l}\text { Offsetting of seagrass } \\
\text { (natural capital) by water } \\
\text { treatment factories } \\
\text { (manufactured capital) or } \\
\text { monetary compensation }\end{array}$ & $\begin{array}{l}\text { Weak sustainability } \\
\text { (Pearce and Atkinson, } \\
\text { 1993) }\end{array}$ \\
\hline 2 & $\begin{array}{l}\text { No net loss of natural } \\
\text { capital but loss of } \\
\text { ecosystem services }\end{array}$ & $\begin{array}{l}\text { Natural capital is replaced } \\
\text { by other natural capital } \\
\text { delivering different } \\
\text { ecosystem services }\end{array}$ & $\begin{array}{l}\text { Offsetting of seagrass by } \\
\text { reefs (the provided } \\
\text { bunches of ecosystem } \\
\text { services are not } \\
\text { necessarily the same) }\end{array}$ & $\begin{array}{l}\text { Strong sustainability (low } \\
\text { criteria) (Ekins, 2003) }\end{array}$ \\
\hline 3 & $\begin{array}{l}\text { No net loss of natural } \\
\text { capital and } \\
\text { ecosystem services }\end{array}$ & $\begin{array}{l}\text { Natural capital is replaced } \\
\text { by the same type of natural } \\
\text { capital delivering the same } \\
\text { type of ecosystem services }\end{array}$ & $\begin{array}{l}\text { Offsetting of a } \\
\text { Mediterranean type } \\
\text { seagrass by a Atlantic } \\
\text { type seagrass providing } \\
\text { the same ecosystem } \\
\text { services (the species are } \\
\text { not necessarily the same) }\end{array}$ & $\begin{array}{l}\text { Strong sustainability } \\
\text { (medium criteria) }\end{array}$ \\
\hline 4 & $\begin{array}{l}\text { No net loss of } \\
\text { biodiversity }\end{array}$ & $\begin{array}{l}\text { Natural capital is replaced } \\
\text { by the same natural capital }\end{array}$ & $\begin{array}{lrr}\text { Offsetting of } & \text { a } \\
\text { Mediterranean } & \text { type } \\
\text { seagrass by } & \text { a } \\
\text { Mediterranean } & & \text { type } \\
\text { seagrass } & & \end{array}$ & $\begin{array}{l}\text { Strong } \begin{array}{r}\text { sustainability } \\
\text { (high } \\
\text { 1991) }\end{array} \\
\text { criteria) (Daly, }\end{array}$ \\
\hline 5 & $\begin{array}{l}\text { No loss } \\
\text { biodiversity }\end{array}$ & $\begin{array}{l}\text { Natural capital is not } \\
\text { replaceable }\end{array}$ & $\begin{array}{l}\text { It is not acceptable to } \\
\text { destroy any kind of } \\
\text { biodiversity }\end{array}$ & Very strong sustainability \\
\hline
\end{tabular}

Source: Adapted from Levrel et al. (2012) and Quétier et al. (2014).

Between level 4 and level 5, a level aiming for a NNL of both biodiversity and ecosystem services could have been added. It would lead to replace natural capital by the same natural capital (i.e. the same species or habitat) 
while also paying attention that the people who used to benefit from ecosystem services provided by the impacted area still benefit from a similar flow of ecosystem services once the biodiversity offset has been carried out, which can be of importance in some developing countries where impacts on priority ecosystem services may threaten human population livelihoods and existence. Jacob et al. (2016) highlight that such an equivalency level must not substitute the ecosystem services approach for the same natural capital approach. However, the ecosystem services approach can be complementary if it is carried out in a second step when the NNL of biodiversity has been secured, in order to make BO more equitable for impacted human populations. This would lead toward a high criterion of strong sustainability regarding both ecological and social criteria.

Another factor of importance is the temporal dimension of substitution. The duration of the offsetting should correspond to the duration of the impact. Thus, for irreversible and definitive impacts (which is often the case), legal instruments should guarantee the perpetual protection of vulnerable and unique lands on which the offsetting will be carried out. As far as we know, these types of legal instruments exist in the US in the form of perpetual conservation easements (Vaissière and Levrel, 2015) - even if environmental law research often questions legal stability and immunity of perpetual conservation easements - but not in most of the countries where the offsetting regulations are implemented. Some countries even seem to have legal incompatibility with the principle of perpetual commitment while it seems essential from a conservation point of view.

Overall, if there are clearly major obstacles when moving from weak to strong sustainability, the reason is not economic per se. The way BO policies are applied and the possible opportunist behaviors often draw back the level of strong sustainability to the bottom. However, some countries are obviously moving toward higher criteria of stronger sustainability. This progress is often coupled with institutional innovations and new organizational forms to face the currently highlighted limits of $\mathrm{BO}$ policies. For instance, in allowing better chances of success and protection of restored area or in improving the capacity to control and monitor BO projects from the beginning to the long run. Aside from the pivotal idea of "weak" vs. "strong" sustainability, $\mathrm{BO}$ is also very often encapsulated in a rhetoric tied to commodification, marketization and privatization. These debates, however, generally result from misunderstandings and deserve clarifications.

\section{3 - What does biodiversity offsetting has to do with commodification, marketization and privatization of Nature?}

Among others, these three terms are often used to criticize the BO concept or the various tools to implement it such as mitigation banking. We want here to briefly clean up some induced misunderstandings related to this phrasing, even if a deeper discussion would be necessary in each of the different contexts of their usage.

There are several understandings of the commodification notion. The restricted definition of commodification is the transformation of entities into commodities. From this point of view, what is "exchanged" as a biodiversity offset is not the restored habitat itself but the service of providing an ecological lift coming from restoration actions. Therefore, there is no commodification because, strictly speaking, no commodities are created. The transformation of old farmlands devoted to cattle farming and sylviculture into a biodiversity offset can even be seen as a de-commodification because milk, meat or wood are commodities. The idea of commodification is however not limited to its economic acceptation. Several authors have for instance adopted a wider definition whereby commodification is simply seen as the process of making things exchangeable (e.g. Appadurai, 1986) or as a proxy commodification that not necessarily needs to get nature alienable or individualizable (Castree, 2003). From this second point of view, the very principle of BO can be seen as a commodification process (Dauguet, 2015). Interestingly Hahn et al. (2015) have even proposed to classify the different types of BO in different degrees of commodification. Finally, whether it is considered as a strict commodification or not, we believe the important point is rather to carefully control the rules for defining and implementing a restoration action as in any type of exchange.

This leads us to the next step: the rules for the exchange. Is there necessarily a marketization of Nature within the BO context, as often criticized in the general public, political and sometimes academic spheres? First, the term marketization is often used interchangeably with commodification. This misleads people believing that BO necessarily induces the creation of "real" markets (Castree, 2008, 2010; Dauguet, 2015). In fact, the BO 
principle and its initial - and still most widespread - way of implementation has nothing to do with marketization. The confusion is probably induced by the very specific case of mitigation banking: the organizational innovation that has been created to overcome former types of BO in the US for wetlands regulations (or conservation banking for endangered species regulations). The principle of mitigation banking is to allow people to invest in advance in ecological restoration actions for which several different developers will pay afterwards in order to meet their BO requirements (with the same NNL goal). We will not discuss the pros and cons of this tool, but recent papers have shown that this specific BO is a hybrid regulation system combining market and regulatory characteristics (Vaissière and Levrel, 2015; Boisvert, 2013), rather than a conventional market as it is often claimed (Bayon and Jenkins, 2010; Spash, 2015; Walker et al., 2009). However, here again the flaws of this system are numerous. Its relevance relies on strong and well-defined rules regarding for instance ecological equivalence, the location of offsets compared to impacts or long term protection of restored area. Even if not all the similar existing or emerging tools worldwide have an institutional framework as advanced and stabilized as in the US, none can be considered as having settled a free market of biodiversity.

$\mathrm{BO}$, and especially mitigation banking, are also often said to lead to a privatization of public goods. It is true that in some cases, and especially in developing countries where property rights are less clearly defined, the transformation of previously cultivated or used land into inaccessible restored habitats may be seen as a privatization of biodiversity. To some extent, expropriation resulting from $\mathrm{BO}$ projects can also be viewed as a privatization from the former owner and the potential lessees" perspective. However, we believe that most of the time the implementation of an offset rather involves yielding private rights to the public. First, the lands on which the impacts and the offset occur are often already private. If the restoration occurs on a public land, it remains public even if some uses are forbidden for conservation reasons. Second, the very principle of BO leads to remove the private use rights of the owner, except if these uses do not interfere with the environmental objectives of the management plan of the measure. In summary, a large part of private property rights (private goods) is transformed into public property rights (club or even public goods) contrary to what is often claimed. Unfortunately, the lands where biodiversity offsets for definitive impacts are set are most often not protected by perpetual conservation easement so the owner recovers his or her right to develop the land. This sad empirical argument also goes against the claim that BO leads to a privatization of Nature. However, in the US where perpetual conservation easements linked to each wetland mitigation bank remove the private right of the current and any future owner to develop his or her lands in perpetuity, 10,000 ha of wetlands are thus "de-privatized" per year (Madsen et al., 2011).

\section{Conclusion: conservation implications}

We first showed that from an economic point of view the very concept of BO is not simply a mainstream economics approach based on a weak sustainability criterion but quite the opposite. It is, at least in principle, a conceptual improvement compared to previous monetary approaches and can help to move toward strong sustainability. In practice, however, the willingness and possibility to use $\mathrm{BO}$ as a true conservation tool is context dependent. Secondly, we argued that although BO can be seen as part of a commodification process, it is neither leading to the marketization of biodiversity, nor to its privatization. There are real reasons to criticize the current implementation of $\mathrm{BO}$ worldwide but this is precisely why one should work on their sizing, definition, rule and good application. Indeed, if BO remains ill-defined and trapped in major confusions there is a risk that they remain at the stage of "paper offsets" (Quétier et al. 2014) just as protected areas can stand for "paper parks".

The practical implication for conservation of a clarification of strengths and limits of $\mathrm{BO}$ is to go beyond ideological disputes to understand why and how BO is used in many countries. An important research avenue lies in the ecological basis for moving to stronger sustainability and higher criteria, as the main constraint on BO remains above all the ecological feasibility of restoration. While it is acknowledged that it is impossible to achieve complete restoration of an ecosystem's biological structures and functions after its deterioration, one can try to get closer to the no net loss horizon. Indeed, the success rate of ecological restoration actions is quite high (70\% and 80\%, Benayas et al., 2009; Jones and Schmitz, 2009; Moreno-Mateos et al., 2012) and can also be improved. For instance, Jones and Schmitz highlighted that restoration recovery not only depends on the type of habitat and the type of degradation that the ecosystem has suffered, but also on the indicators used to assess the rate of renewal. Moreno-Mateos et al. showed that the rate of success of restoration of wetlands depends on the size of the area considered, the level of connectedness and the type of climate. The larger the size of the 
restoration projects, the higher are the chances of success (100\% for biophysical structure over 100 ha). In contrast, when the climate is cold and the connectedness is low, the chance of success of a wetland restoration project is low.

This is where ecology and conservation science have a major role to play to set the boundaries of biodiversity offsets and to improve the relevance of existing projects. Among crucial contributions, the identification of vulnerable, unique and non-replaceable biodiversity components should be better emphasized. Besides, some international initiatives have already begun to adopt these logics such as the 2016 IUCN Policy on Biodiversity Offsets that mentions "no go areas". However, we believe that BO shall not be restricted to the issue of their ecological feasibility but must rather be considered at the cross-roads of multiple issues including economic, social and ecological dimensions. All the aforementioned questions must be integrated to discussions including scientists of different fields, local human populations affected by the application of $\mathrm{BO}$ and decision-makers. The final relevance for conservation will strongly depend on the territory in which the offsetting is applied, how it is applied and for what purpose.

\section{Acknowledgements}

We thank the anonymous reviewers and Vincent Devictor for pertinent suggestions and insightful comments. 


\section{References}

Appadurai A. (ed.), 1986. The Social Life of Things: Commodities in Cultural Perspective. Cambridge: Cambridge University Press.

Apostolopoulou E., Adams W.M., 2015. Biodiversity offsetting and conservation: reframing nature to save it, Oryx : 1-9.

Aubertin C., Couvet D., Flipo F., 2016. Une « marchandisation de la nature »? De l'intégration de la nature en économie, Revue du MAUSS permanente, 9 février 2016 [en ligne].

Bayon R., Jenkins M., 2010. The business of biodiversity, Nature 466 : 184-85.

Benayas J.M.R., Newton A.C., Diaz A., Bullock J.M., 2009. Enhancement of biodiversity and ecosystem services by ecological restoration: A meta-analysis, Science 325 : 1121-1124.

Boisvert V., Méral P., Froger G., 2013. MBIs for ecosystem services: institutional innovation or renovation?, Society and Natural Resources 26(10) : 1122-1136.

Brown B., Hanson M.E., Liverman D.M., Merideth R.W., 1987. Global sustainability: Toward definition, Environmental Management 11(6) : 713-719.

Calvet C., Ollivier G., Napoleone C., 2015. Tracking the origins and development of biodiversity offsetting in academic research and its implications for conservation: A review, Biological Conservation 92 : $492-503$.

Castree N., 2003. Commodifying what nature ?, Progress in Human Geography 27(3) : 273-297.

Castree N., 2008. Neoliberalising nature: the logics of deregulation and reregulation, Environment and Planning A $40: 131-152$.

Castree N., 2010. Neoliberalism and the Biophysical Environment 1 : What „Neoliberalism » is, and What Difference Nature Makes to it, Geography Compass 4(12) : 1725-1733.

Costanza R. (ed.), 1991. Ecological economics: The science and management of sustainability, Columbia University Press, New York.

Daly H., 1991. Elements of environmental macroeconomics, in Costanza R. (ed.), 1991. Ecological economics; the science and management of sustainability, Columbia University Press, New York.

Dauguet B., 2015. Biodiversity offsetting as a commodification process: A French case study as a concrete example, Biological Conservation 192 : 533-540.

Devictor V., 2015. When conservation challenges biodiversity offsetting, Biological Conservation 192 (including a special issue on Biodiversity Offsetting pp. 483-559) : 483-484

Ekins P., 2003. Identifying critical natural capital: conclusions about critical natural capital, Ecological Economics 44 (2-3) : 277-292.

Feydel S., Bonneuil C., 2015. Prédation. Nature, le nouvel eldorado de la finance, Paris : La Découverte.

Fressoz J.-B., 2013. Payer pour polluer. L'industrie chimique et la compensation des dommages environnementaux, 1800-1850, Histoire \& Mesure (XXVIII-I) : 145-186.

Gordon A., Bull J.W., Wilcox C., Maron M., 2015. Perverse Incentives Risk Undermining Biodiversity Offset Policies, Journal of Applied Ecology 52 (2) (April 1): 532-537.

Hahn T., McDermott C., Ituarte-Lima C., Schultz M., Green T., Tuvendal M., 2015. Purposes and Degrees of Commodification: Economic Instruments for Biodiversity and Ecosystem Services Need not Rely on Markets or 
Monetary Valuation, Ecosystem Services (16) : 74-82.

Hicks J.R., 1939. The foundations of welfare economics, Economic Journal 49 : 696-712.

Hough P., Robertson M., 2009. Mitigation under section 404 of the clean water act: where it comes from, what it means, Wetlands Ecology and Management 17(1) : 15-33.

IUCN (International Union for Conservation of Nature and Natural Resources), 1980. World conservation strategy: living resource conservation for sustainable development, IUCN, Morges, Switzerland.

Ives C.D., Bekessy A.A., 2015. The ethics of offsetting nature, Frontiers in Ecology and the Environment 13(10) : 568-573.

Jacob C., Vaissière A.C., Bas A., Calvet C., 2016. Investigating the inclusion of ecosystem services in biodiversity offsetting, Ecosystem Services 21: 92-102.

Jones H.P., Schmitz O.J., 2009. Rapid recovery of damaged ecosystems, PLoS ONE, 4, e5653.

Kaldor N., 1939. Welfare propositions of economics and interpersonal comparisons of utility, The Economic Journal 49(195) : 549-552.

Levrel H., Frascaria N., Hay J., Martin G., Pioch S. (eds.), 2015. Restaurer la nature pour atténuer les impacts du développement. Analyse des mesures compensatoires pour la biodiversité, Collection Synthèses, Editions Quae.

Levrel H., Hay J., Bas A., Gastineau P., Pioch S., 2012. Coût d'opportunité VS coût du maintien des potentialités écologiques : deux indicateurs économiques pour mesurer le coûts de l'érosion de la biodiversité, Natures, Sciences, Sociétés $20: 16-29$.

Levrel H., Missemer A., 2016. Leéconomicisation de la nature, réalités historiques et mythes contemporains, FAERE Working Paper, 2016.24.

Mack J.J., Micacchion M., 2006. An ecological assessment of Ohio Mitigation Banks: Vegetation, Amphibians, Hydrology, and Soils, Ohio EPA Technical Report WET/2006-1. Columbus, Ohio: Ohio Environmental Protection Agency, Division of Surface Water, Wetland Ecology Group.

Madsen B., Carrol N., Kandy D., Bennett G., 2011. 2011 Update. State of Biodiversity Markets Report: Offset and Compensation Programs Worldwide, Ecosystem Marketplace, Washington.

Maron M., Bull J.W., Evans M.C., Gordon A., (2015). Locking in loss : baselines of decline in Australian biodiversity offset policies, Biological Conservation 192 : 504-512.

Matthews J.W., Endress A.G., 2008. Performance criteria, compliance success, and vegetation development in compensatory mitigation wetlands, Environmental Management 41 : 130-141.

Moreno-Mateos D., Power M.E., Comin F.A., Yockteng R., 2012. Structural and functional loss in restored wetland ecosystems, PLoS Biology, 10 (1), e1001247.

Pearce D.W., Atkinson G.D., 1993. Capital theory and the measurement of sustainable development: an indicator of "weak" sustainability, Ecological Economics 8 : 103-108.

Quétier F., Regnery B., Levrel H., 2014. No net loss of biodiversity or paper offsets? - A critical review of the French no net loss policy, Environmental science and policy 38 : 120-131.

Quigley J. T., Harper D.J., 2006. Compliance with Canada's Fisheries Act: a field audit of habitat compensation projects. Environmental Management 37 : 336-350.

Robertson M.M., 2004. The neoliberalization of ecosystem services: wetland mitigation banking and problems in environmental governance. Geoforum 35 (3) : 361-373. 
Spash C., 2015. Bulldozing biodiversity: The economics of offsets and trading-in Nature, Biological Conservation 192 : 541-551.

Vaissière A.C., Levrel H., 2015. Biodiversity offset markets: what is this really about? An empirical approach of wetlands mitigation banking, Ecological Economics $110: 81-88$.

Walker S., Brower A.L., Stephens R.T.T., Lee W.G., 2009. Why bartering biodiversity fails, Conservation Letters 2 : 149-157. 